\title{
ASPECTS OF THE MASCULINE
}

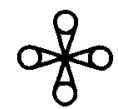

$$
\text { from }
$$

The Collected Works of C. G. Jung

Volumes 4, 5, 7,8,9 i, Io, I3, I4

BOLLINGEN SERIES XX

C. G. Jung: Letters

BOLLINGEN SERIES XCV

C. G. Jung Speaking

BOLLINGEN SERIES XCVII

C. G. Jung: Seminar on Dream Analysis BOLLINGEN SERIES XCIX 



\section{ASPECTS OF THE \\ MASCULINE}

$$
\text { C. G. JUNG }
$$

TRANSLATED BY R.F.C. HULL INTRODUCTION AND HEADNOTES $B Y$ JOHN BEEBE

$$
\text { 类 }
$$

BOLLINGEN SERIES

PRINCETON UNIVERSITY PRESS 


\title{
COPYRIGHT $\odot 1989$ BY PRINCETON UNIVERSITY PRESS
}

41 WILLIAM STREET, PRINCETON, NEW JERSEY

\author{
All Rights Reserved \\ SECOND PRINTING, 1989 \\ THIRD PRINTING, 1991
}

$10 \quad 98$

Extracts from the Collected Works of C. G. Jung: "The Origin of the Hero" and "The Battle for Deliverance from the Mother," Volume 5 , Symbols of Transformation, copyright (C) 1956 by Bollingen Foundation, Inc. "The Stages of Life," Volume 8, The Structure and Dynamics of the Psyche, copyright (c) 1960 by Bollingen Foundation, Second Edition copyright $\mathbb{C} 1969$ by Princeton University Press. "On the Psychology of the Unconscious" and "The Personal and the Collective Unconscious," Volume 7, Two Essays on Analytical Psychology, copyright (C) 1953 by Bollingen Foundation, Inc., new material copyright $(\mathcal{C} 1966$ by Bollingen Foundation. "The Love Problem of a Student," Volume 10, Civilization in Transition, copyright $\odot 1964$ by Bollingen Foundation, Second Edition copyright $(\mathcal{C} 1970$ by Princeton University Press. "The Significance of the Father in the Destiny of the Individual," Volume 4, Freud and Psychoanalysis, copyright (C) 1961 by Bollingen Foundation. "The Personification of the Opposites," Volume 14, Mysterium Coniunctionis, copyright (c) 1963 by Bollingen Foundation, Second Edition copyright $\left(\mathcal{C} 197^{\circ}\right.$ by Princeton University Press. "Concerning the Archetypes with Special Reference to the Anima Concept" and "The Phenomenology of the Spirit in Fairytales," Volume 9, i, The Archetypes and the Collective Unconscious, copyright $\mathbb{C} 1959$ by Bollingen Foundation, Inc., new material copyright (C) 1969 by Bollingen Foundation. "The Spirit Mercurius," Volume 13, Alchemical Studies, copyright $\mathbb{C} 1967$ by Bollingen Foundation.

Extracts from other sources: "Lecture VIII, 13 March 1929, Dream [1 2]" and "Lecture V, 19 February 1930, Dream [23]," Seminar on Dream Analysis, copyright $@ 1984$ by Princeton University Press. "Letter of 12 November 1957," Volume 2 of the C. G. Jung: Letters, copyright (C) 1975 by Princeton University Press. "Letter of 26 August 1943," Volume 1 of the C. G. Jung: Letters, copyright (O 1973 by Princeton University Press. "The Houston Films" (C) 1964 and 1976 by Richard I. Evans) and "Esther Harding's Notebooks" (C) 1975 by C. G. Jung Foundation for Analytical Psychology, Inc.), C. G. Jung Speaking, copyright (C 1977 by Princeton University Press.

All the volumes composing the Collected Works constitute number XX in Bollingen Series, under the editorship of Herbert Read, Michael Fordham, and Gerhard Adler; executive editor, William McGuire. Seminar on Dream Analysis, Bollingen Series XCIX, edited by William McGuire. C. G. Jung: Letters, Volumes 1 and 2, Bollingen Series XCV, under the editorship of Gerhard Adler and Aniela Jaffé, and translated by R.F.C. Hull. C. G. Jung Speaking, Bollingen Series XCVII, edited by William McGuire and R.F.C. Hull.

LIBRARY OF CONGRESS CATALOG NUMBER: 88-37903

ISBN $0.691-01884-7$

First Princeton/Bollingen Paperback Edition, 1989

ISBN-13: 978-0-691-01884-3 (pbk.) 